\title{
Utilizing Nautical Tradition Value Through Ethnoastronomy in Learning Social Science
}

\author{
Erlina Wiyanarti \\ Department of Social Studies Education \\ Faculty of Social Studies Education \\ Universitas Pendidikan Indonesia \\ Bandung, Indonesia \\ erlina.wiyanarti@upi.edu
}

\author{
Mina Holilah \\ Department of Social Studies Education \\ Faculty of Social Studies Education \\ Universitas Pendidikan Indonesia \\ Bandung, Indonesia \\ mina.holilah@upi.edu
}

\begin{abstract}
This article explains about study in utilizing nautical tradition value of Indonesian coastal people in learning social science. The study focused on wealth of nautical tradition values through ethnoastronomy in daily life of coastal people as local wisdom. Those values are implemented afterwards in learning cultural-based social science. The results of the study show that Indonesian coastal people have utilized astronomy science as local wisdom in form of: 1) interpretation of sailing time; 2) disaster mitigation wisdom; and 3) folklore about relationship between human, animal, ocean, and universe. Utilizing nautical tradition value in learning social science is implemented in integrated manner by developing learning plan equipment based on culture including materials, sources, methods, media, and learning evaluations. Through developing this learning plan, learners are expected to have a knowledge, attitude, and skills in understanding their surrounding according to learning social science competence in complete series of 2013 curriculum documents.
\end{abstract}

Keywords-Nautical Tradition Value; Ethno-astronomy; Ethno-pedagogy; Learning Social Science

\section{INTRODUCTION}

Study about exploration of nautical tradition values through ethno-astronomy approach is based on importance of increasing the nautical potency in global competitiveness of national development. Indonesia is the biggest maritime country in the whole world with the largest ocean and the long coastline [1]. Indonesia's land areas are approximately $2.012 .402 \mathrm{~km}^{2}$ and ocean areas are 5.8 million $\mathrm{km}^{2}$ (or as big as $75.5 \%$ of the Indonesia's overall area), consisting of $2.012 .392 \mathrm{~km}^{2}$ of inland waters, 0.3 million $\mathrm{km}^{2}$ territorial sea, and 2.7 million $\mathrm{km}^{2}$ of Exclusive Economic Zone (EEZ) with $95.181 \mathrm{~km}^{2}$ coastline.

The vast ocean makes a strategic maritime and marine sector for Indonesia reviewed in economics, social, culture, and environment. This condition provides qualified benefit for Indonesia especially fishermen and coastal people. However, as it is not as expected, there are many problems since the utilization of ocean has not been done optimally.

Ocean in various parts of Indonesia has not been utilized due to the lack optimization of the wealth of nautical archipelago values. Ocean damage due to environment contamination, poverty of fishermen, lack of local technology development of coastal people, and low awareness of the young generation -learner- regarding the preservation of nautical value, become the main reason that nautical tradition value of Indonesia must be re-excavated and always preserved by continuing to bequeath it. One of means of nautical value heritance is through learning social science in school. Social science is one of subjects that are relevant to these needs by emphasizing aspects of mastery of knowledge, attitude, and skills in solving problem in surrounding environment [2].

Some of the previous researchers show that Indonesia is wealthyin nautical tradition values as a matter of fact, yet these values have not been explored well so that they are less widely utilized in the field of learning in school [3]. Therefore, this article seeks to provide a design idea of learning cultural-based social science, exploring the nautical tradition value through ethno-astronomy approach as one of the studies that are usually only used by people of science. Through the ethno-astronomy approach, study from social science perspective is expected to give a real contribution in the development of learning to solve various problems of local coastal people.

\section{LITERATURE REVIEW}

Indonesia maritime potential that is now being stretched would require more support from various stakeholders in order to be able to be competitive in the global event. One of these efforts is by introducing the maritime culture to the learners as the next generation of the nation through the utilization of local wisdom values of coastal people in learning social science. In general, the development design is described in the paradigm of though in Figure 1. 


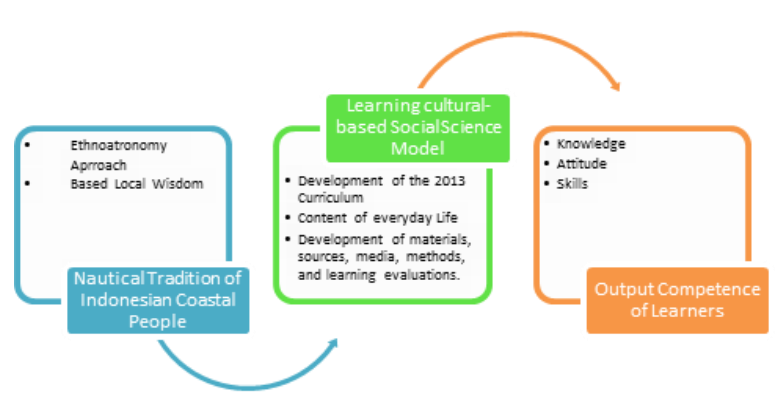

Fig. 1 Paradigmof thought

Paradigm of thought shown in Figure 1 illustrates the nautical tradition value of Indonesia coastal people utilized in the development of cultural-based social science which contains everyday life according to the design of the 2013 curriculum, collaborated in materials, sources, media, methods, and learning evaluations. Thus, learners are expected to be able to have knowledge, attitude, skills, and be responsive in facing marine issues in their surrounding.

Knowledge of nautical local wisdom in social science is very important as an effort to preserve the environment and human survival, as stated by Thornton and Scheer (2012) as follows[4]:

Local and traditional ecological knowledge being used to provide historical and contemporary baseline information, suggest stewardship techniques, improve conservation planning and practice, and to resolve management disputes.

Development of learning cultural-based social science is one effort to preserve local wisdom of local people. Culture is part of the uniqueness of society in the form of creation, taste, intention, and the work which are born from the collective ability to think [5]. Culture is a complex thing that includes knowledge, belief, art, moral, law, customs, abilities, habits gained by human being as a member of society [6]. Through social science learning, it is expected that the potential of local culture could be explored and passed down to the next generations.

\section{Result AND Discussion}

The results of the research include two major aspects of the identification of nautical tradition values among Indonesia coastal people in the approach of ethnoastronomy and implementation in learning plan development of social science in junior high school. Specifically explanations of each aspect are described as follows.

\section{A. Nautical Tradition Values of Coastal People in Ethoastronomy Approach}

Ethno-astronomy is a study of the relationship between astronomy and cultural society in the past. Astronomy has become part of the life of Sundanese, Javanese, Lombok, and even the east of Indonesia in Papua. For example, the life in Javanese society has the imagination of constellation such as Waluku (Orion), Wuluh (Pleaiden), Kalapa Doyong (Scorpio), Sapi Gumarang (Taurus), and others. The constellations are also used in everyday life as a determinant of planting time, means of worship, calendar, and navigation.

In cultural studies, Indonesia has used astrology to determine day and night, tides, the flowering period and the fruiting of plants, and the migration and breeding of animals. The natural phenomenon is a reflection of the passage of time; in a certain position they will be able to know the time to start farming or sailing. Calendars may change, but micro and macrocosmic cycles are always in tandem. For example, the durian will bear fruit when sapigumarang is in the east at dawn, or duku will bear fruit when gubugpenceng is in the east of rembangpetang. In addition, the construction of the temples in the past also has links with astronomy. One of them is Borobudur which was also estimated to be built as an invisible sign of Polaris from Java. At that time, polarization is seen in the horizon, a star that we cannot see anymore because of the precession of earth.

Another aspect in the study of ethno-astronomy is related to the mythology of the sky, for example the mythology about batarakala who swallows the sun so that an eclipse occurs, or a Bimasakti (Milky Way) that describes Bima who leaves into the sea and bitten by snake. In west Java there is Nini Anteh mythology which tells when the moon is full, you can see granny who sit near anteh-tool (loom), having fun accompanied by her cat. The mythology of the ocean bond into the sky is reflected in various sea rituals in different parts of Indonesia in honor of the "Ocean Ruler" that bonds to the cosmos and the microcosms of the universe. One of traditional ceremonies is Sangal from Bajo ethnic that perform during the famine season of fish and other marine species, at one moment they will release the population of species into the sea. Other rituals include: Mappadensasi Mandar ethic in southeast Sulawesi; Buang Jong/Jung in Sawang ethnic society of Bangka Belitung; Sedekah Laut in various coastal areas of Java Island such as Pekalongan, Pacitan, Bantul, Cilacap, Tegal Simah Sea in Pandaran Sampit beach of central Kalimantan.

The rituals are held before or after sailing. They are usually done before the west wind season, that is when the wave rise and sea become malignant. Rituals are meant as a conveyor of offerings to the god of the sea, and to seek the safety and abundance of catching fish. In essence, the ritualsare carried out in gratitude for the abundance of fortune, the expectation of abundance fish catching, the safety of work, and blessing of the fortune. The subject is intended and caused them to perform the ritual, call god the creator, supreme master or fear of other supernatural entities symbolized by Mambang Laut, guardians of the sea, subtly creatures, or others. 
Ethno-astronomy studies about mitigation disaster could be studied from the definition of mitigation disaster according to the Decree of the Minister of Home Affairs No 131 of 2003, that mitigation is an attempt to mitigate the consequence caused by disaster that includes preparedness and alertness [7]. In local cultural wisdom perspective, animals such as fish, crocodile, bird, bats, and other wild animals are traditionally observed as natural phenomena which are then instructed as signs of the arrival of natural disaster or agricultural season, such as Pranata Mangsa in central Java society, Kerta Masa in Balinese, Polontara as it called by south Sulawesi people, Nyali for Nusa Tenggara, and Bulan Berladang for Dayak people.

The rise of large fisher around the coast of north Maluku is a natural phenomenon that is a sign of an earthquake. This phenomenon has been believed by the people of north Maluku that has saved them from the eruption of Kiebesi mount in 1988. Specifically the ethnoastronomy study that has been presented can be observed on Table 1 as follows.

TABLE 1 NAUTICAL TRADITION VALUES OF INDONESIAN COASTAL PEOPLE IN ETHNOASTRONOMY APPROACH

\begin{tabular}{|c|c|c|c|}
\hline No & Aspect & Society Tradition & $\begin{array}{c}\text { Nautical Tradition } \\
\text { Value }\end{array}$ \\
\hline 1 & $\begin{array}{l}\text { Interpretation of } \\
\text { sailing time } \\
\text { (Calendar) }\end{array}$ & $\begin{array}{l}\text { Pranata Mangsa in } \\
\text { constellation: } \\
\text { - Waluku (Orion), } \\
\text { - Wuluh (Pleaides), } \\
\text { - Kalapa Doyong } \\
\text { (Scorpio), } \\
\text { - Sapi Gumarang } \\
\text { (Taurus) }\end{array}$ & $\begin{array}{l}\text { - Awareness about } \\
\text { microcosms and } \\
\text { macrocosm existence } \\
\text { - Harmonization } \\
\text { between human and } \\
\text { universe } \\
\text { - Life cycle continuity }\end{array}$ \\
\hline 2 & $\begin{array}{l}\text { Disaster } \\
\text { Mitigation } \\
\text { Wisdom }\end{array}$ & $\begin{array}{l}\text { Ceremonial ritual } \\
\text { (Sangal, Mappadensasi, } \\
\text { Buang Jong/Jung, } \\
\text { Sedekah Laut, etc) }\end{array}$ & $\begin{array}{l}\text { A mutual respect } \\
\text { between human, } \\
\text { universe and "invisible } \\
\text { power" }\end{array}$ \\
\hline 3 & $\begin{array}{l}\text { folklore about } \\
\text { relationship } \\
\text { between human, } \\
\text { animal, ocean, } \\
\text { and universe }\end{array}$ & $\begin{array}{l}\text { Folklore and mythology } \\
\text { (Batara Kala, } \\
\text { Bimasakti, Nini Anteh, } \\
\text { etc) }\end{array}$ & $\begin{array}{l}\text { Creativity and } \\
\text { imagination in universal } \\
\text { phenomenon } \\
\text { interpretation }\end{array}$ \\
\hline
\end{tabular}

Nautical tradition values in Table 1 could be developed in social science by designing learning plan equipment that will be discussed further in the next chapters.

\section{B. Utilizing the Nautical Tradition Value in Learning Plan Development of Social Science in Junior High School}

The design of learning plan equipment is actually summarized in RPP (Lesson Plan). In the 2013 curriculum, the Lesson Plan (RPP) is developed with reference to Kompetensi Inti(Core Competence) that includes religious attitude (KI 1), social attitude (KI 2), knowledge (KI 3), and skill (KI 4). Kompetensi Inti is translated into Kompetensi Dasar (Basic Competence) and Indikator Pembelajaran (Learning Indicator). Teachers design Achievement of Indikator Pembelajaran by paying attention contextually to materials, methods, media, sources, and learning evaluations.

Social science is one of the subjects that has a strategic role in developing contextual issues in the environment around the learners. One of social science functions is a means of inheriting the local wisdom value of social. Marsh C. J. (2008) reveals that social science plays an important role in the inheritance of knowledge about public relation with the environment as means of cultural transmission or cultural inheritance in the level of formal education [8]. Thus the inheritance of nautical tradition value is very suitable to be applied in cultural-based social science.

Cultural-based social science is a strategy for creating learning environment and designing learning experience that integrates culture as part of the learning process. In culturalbased social science, culture becomes a means for learners to transform their observations into creative forms and principles about nature so that they act as the reaction of meaning, understanding, and meaning of the obtaining information. Cultural-based social science is divided into three kinds: learning about culture (placing culture as a field of science), learning with culture, and learning through culture.

Utilization of nautical tradition value in learning plan development of social science in junior high school is designed in a model that combines materials, sources, methods, media, and learning evaluations described in Table 2 as follows.

TABLE2 DEVELOPMENT OF LESSON PLAN (RPP) COMPONENTS IN UTILIZING NAUTICAL TRADITION

\begin{tabular}{|c|l|l|}
\hline No & \multicolumn{1}{|c|}{$\begin{array}{c}\text { Learning } \\
\text { Component }\end{array}$} & $\begin{array}{l}\text { Development Aspect about Nautical Tradition } \\
\text { Value in Learning }\end{array}$ \\
\hline 1 & $\begin{array}{l}\text { Achievement } \\
\text { Indicator }\end{array}$ & $\begin{array}{l}\text { - Awareness about microcosms and macrocosm } \\
\text { existence } \\
\text { - Knowledge to keep sustainability of life } \\
\text { - Mutual respect } \\
\text { - Creativity and Imagination }\end{array}$ \\
\hline 2 & Material & $\begin{array}{l}\text { - Natural resources potency in surrounding } \\
\text { environment }\end{array}$ \\
& & $\begin{array}{l}\text { Ocean and Nautical Potency } \\
\text { - Social, Culture, and Economic Potency of } \\
\text { Coastal People }\end{array}$ \\
\hline 3 & $\begin{array}{l}\text { Method/ Cultural-based Learning } \\
\text { - Local Wisdom based Learning } \\
\text { - Problem Based Learning } \\
\text { - Contextual Teaching and Learning }\end{array}$ \\
\hline 4 & Source and Media & $\begin{array}{l}\text { - Local People } \\
\text { - Surrounding Natural Environment } \\
\text { - Learning Media: Multimedia }\end{array}$ \\
\hline 5 & Evaluation & $\begin{array}{l}\text { Authentic evaluation (Project, Product, } \\
\text { Performance) }\end{array}$ \\
\hline
\end{tabular}




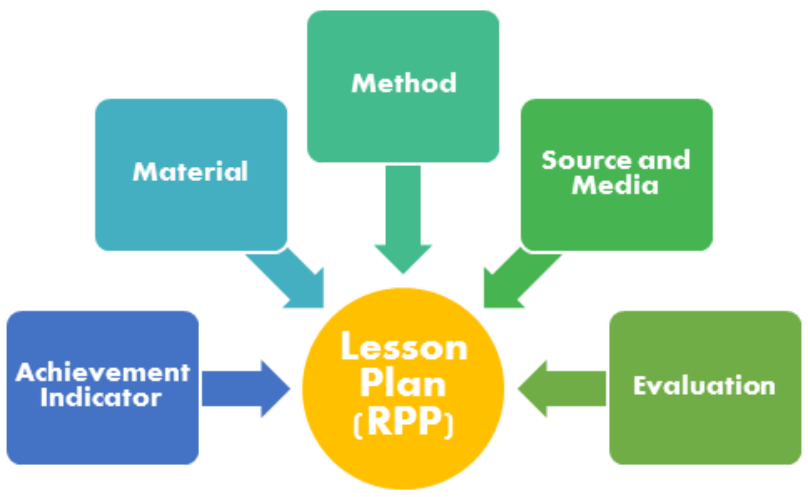

[7] Keputusan Menteri Dalam Negeri RI No. 131 tahun 2003

[8] C. Marsh, Studies of Society and Environment, Exploring the Teaching Possibilities, Pearson: Sydney, 2008

Fig 2. will be further mapped in more detail in Table 2 as follows.

The design of lesson Plan (RPP) development in Table 2 could be developed by teacher according to creativity and needs in the local area. The nautical tradition value is passed down to learners through social science learning which is packed in such way in Lesson Plan (RPP) and practiced in cultural-based social science. Contextual issues become highly relevant to discuss, especially regard to local maritime issues and their utilization. Thus, it is expected that learners can have an extensive knowledge, wise attitude, and skills in solving problem in society.

\section{CONCLUSION}

According to the study that has been presented, it can be concluded that nautical tradition values could be utilized in social science through the packaging of integrated Lesson Plan (RPP) between indicator of achievement, materials, methods, sources, media, and learning evaluations. The ethno-astronomy approach enables the content of everyday life to be an important study in learning cultural-based social science that equips learner knowledge, attitude, and skills in solving problem in society.

\section{REFERENCES}

[1] Forum Rektor Indonesia, Naskah Akademik Membangun Sinergitas Ekonomi, Lingkungan, Hukum, Budayadan Keamanan untuk Menegakkan Negara Maritim Bermartabat, Medan: Forum Rektor Indonesia, 2015

[2] D.Goleman, Ecological Intelligence: How Knowing the Hidden Impacts of What We Buy Can Change Everything,New York: Broadway Books, 2012

[3] D.Affandy,P.Wulandari, 'An Exploration Local Wisdom Priority in Public Budgeting Process of Local Government Case Study in East Java',International Journal Ecological Resque, Ed. September October 2012, 2012

[3] R. Martin, I. Meliono, Ritual Petik Laut Pada Masyarakat Nelayan Sendang Biru Malang: Sebuah Telaah Budaya Bahari, International Conference of Indonesian Studies (ICSSIS) Fakultas Ilmu Pengetahuan Budaya UI, 9 Agustus 2010, 2010

[3] E. Ottoand A.J. Wohlpart, 'Creating a Culture of Sustainability Infusing Sustainability into the Humanities' Journal of Education for Sustainable Development, Los Angeles: Sage Publication (vol.3 No.2), 2009

[4] T. F. Thornton and A. M. Scheer, 'Collaborative engagement of local and traditional knowledge and science in marine environments: a review', International Journal Ecology and Society, Vol.17 (3), 2012

[5] Koentjaraningrat, Kebudayaan, Mentalitas dan Pembangunan, Jakarta: PT Gramedia, 1990

[6] K. Adimihardja, Dinamika Budaya Lokal, Bandung: CV. Indra Prahasta dan Pusat Kajian LBPB, 2008 